\title{
Correction: DNA damage and S phase- dependent E2F1 stabilization requires the cIAP1 E3-ubiquitin ligase and is associated with K63-poly-ubiquitination on lysine 161/ 164 residues
}

Valérie Glorian ${ }^{1,2}$, Jennifer Allègre ${ }^{1,2}$, Jean Berthelet ${ }^{1,2}$, Baptiste Dumetier ${ }^{1,2}$, Pierre-Marie Boutanquoi ${ }^{1,2}$, Nathalie Droin ${ }^{3}$, Cémile Kayaci ${ }^{1,2}$, Jessy Cartier ${ }^{1,2}$, Simon Gemble ${ }^{1,2}$, Guillaume Marcion ${ }^{1,2}$, Daniel Gonzalez ${ }^{1,2,4}$, Romain Boidot ${ }^{1,2,4}$, Carmen Garrido ${ }^{1,2}$, Olivier Micheau ${ }^{1,2}$, Eric Solary ${ }^{3,5}$ and Laurence Dubrez ${ }^{1,2}$

Correction to: Cell Death \& Disease 8, e2816 (2017); https://doi.org/10.1038/cddis.2017.222; published online 25 May 2017.

Following publication of this article, it was noticed that an error during typesetting had led to the author Olivier
Micheau being listed incorrectly as Olivier Michaud. The publisher would like to apologise for any inconvenience caused.

Published online: 16 July 2018

Correspondence: Laurence Dubrez (Idubrez@u-bourgogne.fr)

'Université de Bourgogne Franche-Comté, LNC UMR1231, Dijon, France

${ }^{2}$ Institut National de la Santé et de la Recherche Médicale (Inserm), LNC

UMR1231, Dijon, France

Full list of author information is available at the end of the article.

(c) The Author(s) 2018

(c) (i) Open Access This article is licensed under a Creative Commons Attribution 4.0 International License, which permits use, sharing, adaptation, distribution and reproduction c. in any medium or format, as long as you give appropriate credit to the original author(s) and the source, provide a link to the Creative Commons license, and indicate if changes were made. The images or other third party material in this article are included in the article's Creative Commons license, unless indicated otherwise in a credit line to the material. If material is not included in the article's Creative Commons license and your intended use is not permitted by statutory regulation or exceeds the permitted use, you will need to obtain permission directly from the copyright holder. To view a copy of this license, visit http://creativecommons.org/licenses/by/4.0/. 